\title{
THE CYCLE OF CUSTOMER VALUE: A MODEL INTEGRATING CUSTOMER AND FIRM PERSPECTIVES
}

\author{
Silvia MARTELO-LANDROGUEZ1 ${ }^{1}$, Carmen BARROSO-CASTRO², \\ Gabriel CEPEDA ${ }^{3}$
}

\author{
Management and Marketing Department, Universidad de Sevilla, \\ Ramón y Cajal, 1, 41018 Seville, Spain \\ E-mails: ${ }^{1}$ smartelo@us.es (correspondingauthor),2barroso@us.es, 33abi@us.es \\ Received 11 June 2012; accepted 18 January 2013
}

\begin{abstract}
The aim of this paper is to contribute to the strategic management literature by identifying a relationship between customer value seen from the customer perspective and customer value seen from the firm perspective, and how this relationship might affect the value created for the customer. We propose that such a relationship exists, and attempt to create an integrated view of customer value. We have not found any papers that focus on the relationship between these two perspectives of customer value, and our aim is to bridge this gap in the literature. Thus, the authors test, in a quantitative study utilizing structural equation models (SEM), how a firm should create value in order to be perceived by the customers, and how this value could be appropriated in the international banking industry. The results show to the managers that value creation impacts on perceived value but not on value appropriation.
\end{abstract}

Keywords: value, perceived value, value creation, value appropriation, customer value, strategic management.

JEL Classification: M10.

\section{Introduction}

It has long been recognized that the essential elements of a firm's business strategy are understanding the value that customers perceive in an offer, creating value for them and then managing it over time (Chatain, Zemsky 2011; Edvardsson, Oskarsson 2011). In recent decades, firms have been operating in a new and complex competitive environment in which more and more customers are demanding the creation of value (Eichentopf et al. 2011; Sánchez, Iniesta 2006) and firms are increasingly regarding customer value as a key factor in their search for new ways to obtain and maintain a competitive advantage. This has generated a growing interest in creating and delivering superior value to the customer (Mustak et al. 2013; Smith, Colgate 2007; Wang et al. 2004).

The existing literature demonstrates that customer value can be viewed both from the customer's point of view and from the firm's point of view (Martelo-Landroguez et al. 
2013). Some authors focus on perceived value (the customer perspective), while others focus on value creation and appropriation (the firm perspective). But it is important to find an integrated view of both perspectives from which to study customer value. Indeed, we suggest that the unification of these two perspectives is what really creates value. The firm only truly creates value when the customer perceives that value. Therefore, we propose the existence of a relationship between the different perspectives and will attempt to create an integrated view of customer value. It is clear therefore, that the ability of the firm to create and appropriate value needs to encompass the customer perspective. We have not found any papers that focus on the relationship between these different perspectives of customer value, and our aim is to bridge this gap in the literature, and carry out an analysis of how these perspectives can be related. Our objective therefore is a) to identify the relationship between customer value from the customer's point of view and customer value from the firm's point of view; b) to produce a model that shows this potential relationship; and c) to demonstrate that it is this relationship that really creates value.

The paper begins with an explanation of the theoretical context, followed by a presentation of the study model and the positing of our hypotheses. The third section contains a description of the principal aspects of the methodology, including the research context, measures, data collection and analysis. A discussion of the results and implications of the study follows, and the paper concludes with the limitations of the study and suggests further areas of research.

\section{Theoretical background}

The study of 'customer value' is complicated by the different definitions of the concept, depending on the point of view adopted. For example, Payne and Holt (2001) note that the term 'customer value' can be used in a variety of contexts. These include 'customerperceived value', 'creating and delivering customer value' and 'value of the customer'. This paper is based on a study of the three streams of investigation proposed by Payne and Holt (2001): perceived value; value creation; and value appropriation. In our opinion, their approach concurs with our idea of value. On the one hand, marketing literature focuses on the demand perspective of value - customer value and its perception - while on the other hand, strategic management literature views value creation and appropriation (and the firm's ability to carry this out) as the distinctive competence.

Business strategy aims to create firm value, but the real interest lies in appropriating the greatest possible amount of the value created. To achieve this, firms depend not only on their own organizational resources and capabilities, but also on customer perceptions and customer reactions to the firm's value proposition compared to its competitors. We therefore propose this study of value creation from a double perspective: on the one hand, focusing on what needs to happen inside firms in order to develop a value creation capability; while at the same time focusing on customer perceptions, because these determine the extent to which firms can appropriate value. 
These two perspectives should be unified in order to achieve a more realistic understanding of value creation. Our main objective therefore is to connect these two contributions in order to clarify the whole process of value creation.

The value perceived by the customer has received a lot of attention from both academics and practitioners due to the importance of predicting purchase behavior and achieving competitive advantages (Boksberger, Melsen 2011). Sánchez and Iniesta (2006) demonstrate that many terms have been used to refer to perceived value (PV), such as 'judgment value'; 'shopping value'; 'consumption value'; 'relationship value'; 'product value'; 'service value'; 'desired value'; 'expected value'; 'customer value'; 'perceived value'; or 'received value'.

In the review of the PV literature carried out by Woodall (2003), 18 different terms were found that describe the idea of value from the demand side. In fact, some authors use different terms within the same paper. According to Sánchez and Iniesta (2006), these terms all refer to the same idea; that of customers' perception of value.

Although PV has often been defined as a trade-off between quality and price, many researchers note that it is a more obscure and complex construct, which encompasses ideas such as price, quality and perceived benefits and sacrifices (Bolton, Drew 1991).

On the other hand, two processes, which combine and interact with each other, are fundamental to achieving superior customer value by the firms (Mizik, Jacobson 2003). One of the processes involves the creation of customer value, while the other focuses on appropriating value in the marketplace (Ritala, Tidström 2014). Value creation (VC) alone, however, is insufficient for a firm to achieve success in the marketplace; it must also have the ability to restrict competitive forces (such as erecting barriers to imitation) so that it can appropriate some of the value that it has created, in the form of profit (Mizik, Jacobson 2003).

Therefore, due to increasing turbulence and constant changes in the current economic and competitive environment, some authors (Chatain, Zemsky 2011; Nonaka, Toyama 2002; Ritala, Tidström 2014) have recently stressed that for a strategy to be effective it should adopt both $\mathrm{VC}$ and value appropriation (VA).

Similarly, Tuominen (2004) views VC as an organizational capability that, along with the VA capability, is required in order to gain competitive advantage in the marketplace. The superiority of firms that lead the competition cannot be based solely on the creation of value; they also have to be able to appropriate the value created through market share and profits (Ritala, Tidström 2014). In any event, it is likely that these advantages would only be temporary, as market dynamism and uncertainty generate the need not only to create new value, but also to maintain the value created in previous periods (Chatain, Zemsky 2011; Morrow et al. 2007; Sirmon et al. 2007).

Although VC and VA are both required to achieve a sustainable competitive advantage (as shown in Figure 1), firms have to decide the extent to which they will focus on one or the other (Mizik, Jacobson 2003). Firms therefore face the task of balancing the two processes in their strategies and determining the appropriate amount of support for each. 


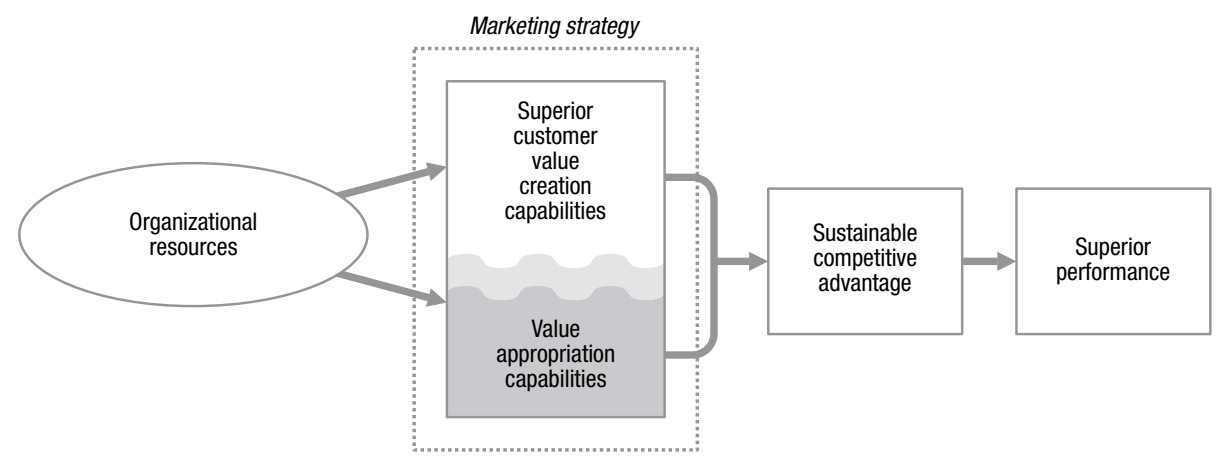

Fig. 1. Marketing strategy and sustainable competitive advantage Source: Mizik and Jacobson (2003).

\section{An integrated view of customer value}

In this section, we attempt to integrate the two perspectives of customer value described above.

There are several arguments that suggest that the customer perspective is a potentially important alternative viewpoint for strategic management (Priem 2007). One argument is that customers should be an important consideration in strategy formation, since company success depends on customers experiencing benefits. Put simply, value creation becomes a precondition for value capture.

As a first approximation of the relationship between these three concepts, we propose the following figure:

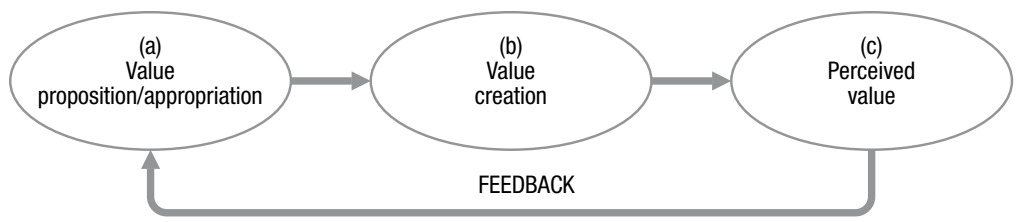

Fig. 2. Customer value cycle

As shown in Figure 2, we propose that the value cycle begins with the firm's proposition of value (a). Every firm has its own value proposition and its own expectation of value capture in the marketplace. We also propose that a firm must be able to create value (b) for its customers. To create value, a firm needs to have or develop a set of distinctive capabilities to differentiate it from the competition. We posit that the value proposition of each firm helps it to create value for its customers. But regardless of how much value a firm creates, if the customer does not perceive it (c), then the firm is not really creating value (Chan et al. 2010; Smith, Colgate 2007). This is where perceived value comes into play.

Some authors identify differences between what managers think their customers value and what customers really value (Woodruff, Gardial 1996). It is important to include 
PV in the model because of the different ways that customers and firms measure value (Nasution, Mavondo 2008).

When a firm creates value and the customer perceives it, the firm then needs to appropriate that created value. We therefore propose that feedback through customer PV is necessary, to enable the firm to update and adapt its value proposition.

As explained earlier, we argue that when discussing the concept of 'customer value', it is important to keep both the customers and the firm in mind, since it is the relationship between them that gives rise to true value. The aim of this study is to identify the nature of the relationship between customer value from both the customer perspective and the firm perspective, to allow improvements in the value created for the customers.

Traditionally, value research has been focused on the evaluation of how firms create value for their customers and how customers perceive the superior value of what the firm is offering, compared with the competition. In recent years, the emphasis has been on considering customers as assets (Ulaga 2001), an idea that refers to the requirement that firms should be able to appropriate the value created.

Although VA is important, strategists should not focus exclusively on capturing exchange value, while leaving it to chance that use value is experienced. Exchange value is the monetary amount realized at the single point in time when the exchange of the product/service takes place and use value equates to the specific qualities of the product/ service that customers perceive in relation to their needs and how far alternative products/services might meet those needs (Bowman, Ambrosini 2000). An essential part of the strategist's art should be to help customers perceive and experience maximum use value, in a competitive environment in which other firms are also struggling to help their customers (Priem 2007). Furthermore, VC alone is insufficient to achieve competitive advantage and financial success and therefore, firms that are unable to restrict competitive forces will not be able to appropriate the value that they have created (Teece et al. 1997). Indeed, there is little incentive for firms to engage in VC in the absence of isolating mechanisms that prevent the immediate dissipation of the profits associated with a value-creating initiative (Mizik, Jacobson 2003).

In Figure 2, we try to demonstrate how the three views of value are equally important for a firm and that all three should be interrelated. Similarly, Martelo-Landroguez et al. (2013) note that, from a firm's perspective, VC starts generating value for the customer, which enables it to gain a competitive advantage, which in turn contributes to increased shareholder wealth (Priem 2007; Sirmon et al. 2007).

Figure 3 is a graphical explanation of the process we propose. 
FIRM

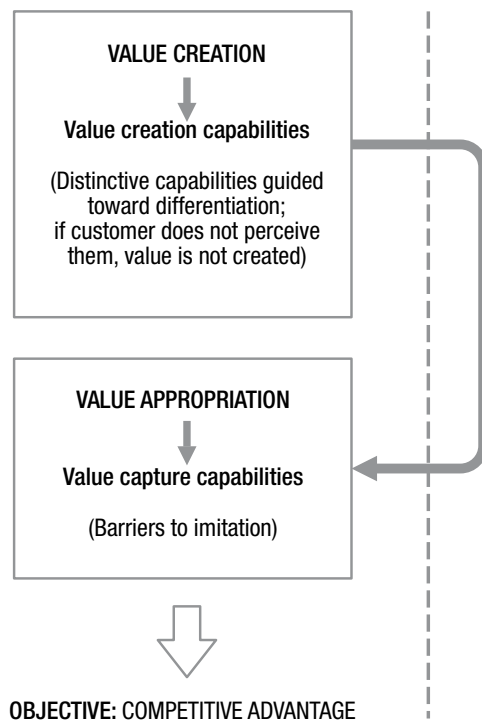

CUSTOMER

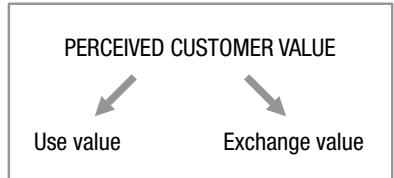

Fig. 3. An integrated view of customer value

We therefore propose the following model:

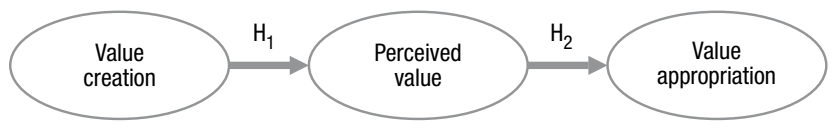

Fig. 4. Value model

We also propose the following hypotheses:

H1: Customer value creation is positively related to customer perceived value.

H2: Customer perceived value is positively related to firm value appropriation.

As we see in Figure 4, our proposed model includes the three views of value and the relationship between them. We would argue that it is this relationship that really creates value.

This means that a firm has to be able to create value for its customers, and in order to create value, it needs to have or develop a distinctive set of capabilities that allows it to stand out from the competition.

Regardless of how much value a firm creates, if the customer does not perceive it, the firm is not really creating value. This is where PV comes into play and with it, the role of the customer.

If, on the contrary, a firm creates value and the customer does perceive it, the next step must be the appropriation of the value it has created. Just as when the firm creates value, it needs to have - or if not, to develop - a set of capabilities, such as barriers to imitation, in order to capture the value created. 


\section{Methodology}

\subsection{Data collection}

The context for the research hypotheses is the Spanish banking industry, including retail and commercial banks and saving banks that serve the general public; representing around $18 \%$ of national GDP, very similar to other international banking systems.

This is a suitable sector for our study because increasingly intense competition within the international financial service industry is forcing banks to recognize the need to seek new ways of creating customer value. In addition to the competitiveness of the industry, the relative intangibility of their products/services creates the need to capture and retain customers by offering them something extra and the need to appropriate the value created for them.

The crisis in this industry is highly significant, both now and in 2010, when the study was carried out. The effect of this international crisis has been to force many countries to apply severe measures to reduce the impact on their financial services industry. Numerous banks and insurance company takeovers and capitalizations have taken place, the number of company mergers as a rescue measure has multiplied and crashes have increased. The full extent of this global crisis is still unknown, since events have occurred at an unusually high speed, leading to enormous changes within a short time span, mostly following the crash of Lehman Brothers in September 2008.

A total of 110 banks were operating in Spain at the time of the study (2010), of which 65 were commercial/retail banks and 45 were savings banks. Only 40 of the 65 commercial/retail banks qualified: of the other 25 banks, 17 simply bore a corporate name, but were the capital property of other banks, operating from within their offices; and eight were investment (not commercial) banks. The target group therefore consists of 85 financial bodies, representing around $77 \%$ of the total.

The small number of bodies comprising the banking industry in Spain can be seen as an advantage or a disadvantage. On the one hand, the study is able to examine the whole population instead of a particular sample, but on the other hand, a small sample size can lead to problems in the analysis of the data.

The response rate was high, at around $90 \%$, with 76 of the 85 banks completing the questionnaire. It is of note that all of the completed questionnaires were valid.

We also gathered data from banking customers to gain a more precise picture of the value generated by the firms. A pool of customer data (with a minimum of 20 to 30 customers) was obtained for each of the 76 banks to observe standard customer behavior regarding PV. The study used 1832 customer questionnaires.

To measure VA, we opted to use secondary data (financial reports) because we believe that this variable should be measured objectively.

We decided to combine these sets of data (from banks and customers) to test the hypotheses in our theoretical model. 


\subsection{Measures}

We measured all of the constructs in the questionnaires against existing scales in the literature, which indicates that all of the instruments in the study have a proven validity and reliability.

Following a review of the scales used in previous investigations, we chose Hooley et al.'s (2005) scale to measure customer VC capability, although the lack of proposals for measuring customer VC created problems when seeking the most appropriate instrument for this construct. The model uses Hooley et al.'s (2005) scale because it is complete and refers to the creation of value for customers, as opposed to other proposals, which analyze VC for all the stakeholders.

The model uses Martin et al.'s (2008) scale to measure customer PV. This consists of four dimensions: service quality (SQ); service equity (SE); confidence benefits (CB); and perceived sacrifice (PS). We believe this scale is well suited to our study, given its emphasis on perceived service value. Furthermore, according to Martin et al. (2008), the scale can be generalized to other contexts.

Using Tuominen's (2004) scale as our basis, we developed a list of variables to help us measure the firm's VA. Data was collected from each bank regarding market share; sales volume; overall profit levels; ROI (return on investment); and profit margins. This data was taken from the annual accounts of each bank posted on its website or from the website of the Spanish Share Market Commission.

Appendix A provides a summary of the questions used in the questionnaire given to both customers and managers.

\subsection{Data analysis}

In order to obtain a robust evaluation of the quality of the items, we carried out a confirmatory analysis (CFA), using the covariance matrix as input, via the EQS 6.1 robust maximum likelihood method (Bentler 1988). The CFA produced a good fit with an incremental fit index (IFI) of 0.93 and a comparative fit index (CFI) of 0.93 (also, Satorra-Bentler $\left.\chi_{(18)}^{2}=40.65 ; \chi^{2} / d . f=2.25 ; C F I=0.93 ; I F I=0.93 ; R M S E A=0.07\right)$. In all the measurements, Bagozzi and Yi's (1988) composite reliability index and Fornell and Larcker's (1981) average variance extracted index was higher than the evaluation criteria of 0.7 for composite reliability and 0.5 for the average variance extracted, as seen in Table 1.

Table 1. Descriptive statistics and discriminant validity

\begin{tabular}{lccccccc}
\hline & Mean & SD & AVE & CR & 1 & 2 & 3 \\
\hline 1. Value creation & 5.3 & 1.2 & 0.63 & 0.82 & $\mathbf{0 . 7 9}$ & & \\
\hline 2. Perceived value & 5.7 & 0.9 & n.a & n.a & 0.15 & n.a & \\
\hline 3. Value appropriation & 0 & 1 & n.a & n.a & 0.12 & -0.29 & n.a \\
\hline
\end{tabular}

Notes: $\mathrm{n} . \mathrm{a}=$ not applicable because they are formative measures. Mean $=$ the average score for all of the items included in this measure; $\mathrm{SD}=$ Standard Deviation; AVE = Average Variance Extracted; the bold numbers on the diagonal are the square root of the Average Variance Extracted, Shared Variances are given in the lower triangle of the matrix; $\mathrm{CR}=$ Composite Reliability. 
We determined the discriminant validity by calculating the shared variance between pairs of constructs (the lower triangle of the matrix in Table 1) and verifying that the value was lower than the average variances extracted for the individual construct (the diagonals in Table 1). The shared variances between pairs of all possible scale combinations indicate that the variances extracted are higher than the associated shared variances in all cases (Fornell, Larcker 1981). In the interest of thorough discriminant validity, we carried out an additional test, which supports this assumption, since the confidence interval ( \pm 2 standard errors) around the estimated correlation between any two latent indicators never includes 1.0 (Anderson, Gerbing 1988).

\section{Results}

After checking the psychometric properties of the measures, the next step was to evaluate the relationships set out in our hypotheses $\mathrm{H} 1$ and $\mathrm{H} 2$. As seen in Table 2, the fit indices of the model are satisfactory $\left(\right.$ Satorra-Bentler $\chi_{(5)}^{2}=28.81 ; \chi^{2 / d} . f=5.76 ; C F I=$ 0.93; RMSEA $=0.14$ ), suggesting that the nomological network of relationships fits the data -another indicator that supports the validity of these scales (Churchill 1979).

Table 2. Goodness-of-fit measures model

\begin{tabular}{lc}
\hline & Model \\
\hline Degree of freedom & 5 \\
\hline Satorra-Bentler & $28.81(\mathrm{p}=0.000)$ \\
\hline Goodness-of-fit index (GFI) & 0.96 \\
\hline Root mean square residual (RMSR) & 0.07 \\
\hline Root mean square error of approximation (RMSEA) & 0.14 \\
\hline Adjusted goodness-of-fit index (AGFI) & 0.88 \\
\hline Normed fit index (NFI) & 0.92 \\
\hline Comparative fix index (CFI) & 0.93 \\
\hline
\end{tabular}

Results of hypothesis testing are presented in Table 3.

Table 3. Summary of results

\begin{tabular}{lllll}
\hline Model & Hypotheses & Supported/Non supported & \multicolumn{2}{c}{$\begin{array}{c}\text { Standardized parameter } \\
\text { estimate }\end{array}$} \\
\hline VC----->PV & $\mathrm{H}_{1}$ & Yes & $0.76^{* *}$ & 0.58 \\
\hline PV----> VA & $\mathrm{H}_{2}$ & No & $-0.24^{* * *}$ & 0.06 \\
\hline
\end{tabular}

As shown in Table 3, there is a significant relationship between VC and PV and VC explains the 58 percent of the variance in PV. Then, hypothesis 1 was supported. Customers are somehow able to perceive the value that is created for them by a firm. 
Results show that perceived sacrifices $(-0.04)$ are not significant for customers when evaluating the service provided by the banks in our study. Conversely, confidence benefits $(0.40)$ and service quality $(0.31)$, followed by service equity $(0.12)$, are important aspects for managers in order to improve customer value perceptions.

Finally, relationship between PV and VA is not significant and thus hypothesis 2 was not supported.

\section{Discussions}

This paper has shown that there are different views and ways of thinking about customer value, depending on the point of view that is adopted: namely, PV (the customer perspective); and VC and VA (the firm perspective).

Furthermore, we try to show the importance of linking the different views of customer value. We argue that when the concept of 'customer value' is discussed, it is important to consider both the customers and the firm, since the relationship between them is what gives rise to value. What we try to show in our study is that the real proxy of value creation is customer perceived value, that is, the firm only truly creates value when the customer perceives that value.

The results from our model confirm hypothesis 1 and do not support hypothesis 2. First, our analysis provides support for hypothesis 1 , as expected VC has a significant positive effect on PV. Thus, once firms create value, the customers are able to perceive it. With regard to the testing of hypothesis 2 , the results confirm that PV has not a positive effect on VA. The negative value of the link between PV and VA is opposite to that which would be expected, indicating that when customer perceived value increases, the value appropriated by the firm decreases.

As it can be seen, it is not logical or reasonable to propose such a relationship, since this would mean that firms should reduce their customer perceived value in order to increase their value appropriation.

From our point of view, a better explanation of this controversial finding can be obtained based on the following two arguments:

1) Managers should not expect instant results of VA with regard to PV. This is supported by the idea that, sometimes, a time lag is needed before one variable affects the other.

2) Primary data used to measure PV were linked to secondary data used to measure VA. Two different data source could have affected the results of our analysis. An alternative could be repeating our analysis linking the entire PV scale to each VA indicator (i.e. market share, sales volume, overall profit levels, ROI, and profit margins), or to VA subjective measures obtained from primary data.

Our paper not only contributes to the literature on both value and firm management, but will also influence the current management of firms with regard to customer VC.

Firstly, we recommend that firms combine VC and VA, rather than focusing on only one of these aspects. As we have discussed, sustainable competitive advantage requires 
both VC and VA (see Fig. 1), and the firm has to decide the extent to which one or other predominates.

Secondly, as an extension of this recommendation, we outline the importance of analyzing the best way to distribute a firm's scarce resources between its VC and VA capabilities. A firm's resources are limited and they need to prioritize the allocation of their resources between their VC and VA capabilities.

Thirdly, the results obtained using the PV scale show the relative significance of each dimension for PV. Without reference to these results, managers might endanger customer value perceptions by concentrating on the less important dimensions of PV instead of pursuing the more important dimensions.

We aim to help managers to identify the key dimensions for increasing customer value perceptions. This will guide them in the best way to allocate their resources. In our case, managers have to focus on increasing service quality, improving service equity and developing confidence benefits. No recommendations were obtained for perceived sacrifice because this dimension was not significant in determining PV.

We also underline the importance of linking VC and customer PV. A firm's VC should be guided by the value perceived by the customers. Irrespective of how much value a firm creates, if customers do not perceive it, then firms are not creating value.

With this in mind, our intention is to identify the nature of the relationship between VC and PV in terms of their components. As Appendix A shows, we refer to value creation for firms in terms of levels of loyalty and satisfaction from the firm point of view. Thus, if firms can successfully translate these elements into products/services, customers will perceive it. Our findings support this assertion because value creation perception for managers has a significant impact on customers' value perceptions.

Finally, our paper identifies a set of capabilities that firms can use to create value and to appropriate the value created. These capabilities can also serve as a reference point for firms seeking to develop other capabilities to facilitate their VC and VA.

\section{Conclusions and future research}

In recent years, customers have become the focus of attention, and every firm seeks to satisfy them in one way or another.

The existing literature demonstrates that customer value can be seen from the point of view of both the customer and the firm, but a relationship between these two perspectives is required in order to study customer value. In this paper, we offer a model that links PV, VC and VA, and demonstrate that it is the relationship between these three concepts that really creates value for the customer.

To sum up, if the customer does not perceive the value created by a firm, this one is not really creating value. If, on the contrary, a firm creates value and the customer does perceive it, the firm must be able to appropriate the value which has created.Then it is possible to say that firm would have completed what we name cycle of customer value. 
With respect to the limitations of our study, the investigation was carried out at a single point in time, which is a particularly limiting because customer value is a dynamic construct. Time has traditionally been considered in the management literature as a constant rather than a variable, a belief Bluedorn (2000) ascribes to people in general. Further, as Bluedorn notes, the belief that time is a constant is deeply institutionalized, which suggests that most people, most of the time, do not even consider the possibility that time may vary. Furthermore, our study was carried out in a single industry (the Spanish banking industry), which does not allow us to generalize the results attained to other economic industries.

It would also be interesting to carry out a more fine-grained analysis of every aspect of the relationship between VC, PV and VA, as it is likely that some kind of interaction can be found between all of these concepts. Although we have initiated this investigation, more extensive studies are necessary.

Finally, it is important to stress the situation that international banking industry was facing at the time of the study. While we believe that this situation provided an ideal opportunity for our study, it also created problems for collecting data for the empirical investigation. Given the high degree of turbulence in this industry at the time and that the international banking and its problems and uncertainties were the subject of much public discussion, some managers were wary of giving out data.

We consider that this investigation provides a starting point for future investigations into the creation of value or its maintenance in the current environment, where the customer is daily more demanding and the competition is stronger. Possible future investigations might extend the timescale of our study and expand into other economic industries, to be able to generalize the results.

\section{References}

Anderson, J. C.; Gerbing, D. W. 1988. Structural Equation modeling in practice: a review and recommended two-step approach, Psychological Bulletin 103(3): 411-423.

http://dx.doi.org/10.1037/0033-2909.103.3.411

Bagozzi, R. P.; Yi, Y. 1988. On the evaluation of structural equation models, Journal of the Academy of Marketing Science 16(1): 74-94. http://dx.doi.org/10.1007/BF02723327

Bentler, P. 1988. Practical issues in structural modeling, in Long, J. S. (Ed.). Common problems/ proper solutions: avoiding error in quantitative research. Newbury Park, CA: Sage Publications.

Bluedorn, A. C. 2000. Time and organizational culture, in N. M. Ashkanasy, C. P. M. Wilderon, M. F. Peterson (Eds.). Handbook of organizational culture and climate. Thousands Oaks, CA: Sage.

Boksberger, P. E.; Melsen, L. 2011. Perceived value: a critical examination of definitions, concepts and measures for the service industry, Journal of Services Marketing 25(3): 229-240.

Bolton, R. N.; Drew, J. H. 1991. A multistage model of customers' assessments of service quality and value, Journal of Consumer Research 17(4): 375-384.

http://dx.doi.org/10.1086/208564

Bowman, C.; Ambrosini, V. 2000. Value creation versus value capture: towards a coherent definition of value in strategy, British Journal of Management 11(1): 1-15.

http://dx.doi.org/10.1111/1467-8551.00147 
Chan, K. W.; Yim, C. K. B.; Lam, S. S. K. 2010. Is customer participation in value creation a doubleedged sword? Evidence from professional financial services across cultures, Journal of Marketing 74(3): 48-64. http://dx.doi.org/10.1509/jmkg.74.3.48

Chatain, O.; Zemsky, P. 2011. Value creation and value capture with frictions, Strategic Management Journal 32(11): 1206-1231.

Churchill, G. A. 1979. A paradigm for developing better measures of marketing constructs, Journal of Marketing Research 16(1): 64-73. http://dx.doi.org/10.2307/3150876

Edvardsson, I. R.; Oskarsson, G. K. 2011. Knowledge management and value creation in service firms, Measuring Business Excellence 15(4): 7-15.

Eichentopf, T.; Kleinaltenkamp, M.; van Stiphout, J. 2011. Modelling customer process activities in interactive value creation, Journal of Service Management 22(5): 650-663.

Fornell, C.; Larcker, D. F. 1981. Evaluating structural equation models with unobservable variables and measurement error, Journal of Marketing Research 18(1): 39-50.

http://dx.doi.org/10.2307/3151312

Hooley, G. J.; Greenley, G. E.; Cadogan, J. W.; Fahy, J. 2005. The Performance impact of marketing resources, Journal of Business Research 58(1): 18-27.

http://dx.doi.org/10.1016/S0148-2963(03)00109-7

Martelo-Landroguez, S.; Barroso-Castro, C.; Cepeda; G. 2013. Developing an integrated vision of customer value, Journal of Services Marketing 27(3): 234-244.

Martin, D.; Gremler, D. D.; Washburn, J. H.; Cepeda, G. 2008. Service value revisited: specifying a higher-order, formative measure, Journal of Business Research 61(12): 1278-1291.

http://dx.doi.org/10.1016/j.jbusres.2008.01.015

Mizik, N.; Jacobson, R. 2003. Trading off between value creation and value appropriation: the financial implications of shifts in strategic emphasis, Journal of Marketing 67(1): 63-76.

http://dx.doi.org/10.1509/jmkg.67.1.63.18595

Morrow, J. L.; Sirmon, D. G.; Hitt, M. A.; Holcomb, T. R. 2007. Creating value in the face of declining performance: firm strategies and organizational recovery, Strategic Management Journal 28(3): 271-283. http://dx.doi.org/10.1002/smj.579

Mustak, M.; Jaakkola, E.; Halinen, A. 2013. Customer participation and value creation: a systematic review and research implications, Managing Service Quality 23(4): 341-359.

Nasution, H. N.; Mavondo, F. T. 2008. Organisational capabilities: antecedents and implications for customer value, European Journal of Marketing 42(3/4): 477-501.

http://dx.doi.org/10.1108/03090560810853020

Nonaka, I.; Toyama, R. 2002. A firm as a dialectical being: towards a dynamic theory of a firm, Industrial \& Corporate Change 11(5): 995-1009. http://dx.doi.org/10.1093/icc/11.5.995

Payne, A.; Holt, S. 2001. Diagnosing customer value: integrating the value process and relationship marketing, British Journal of Management 12(2): 159-182.

http://dx.doi.org/10.1111/1467-8551.00192

Priem, R. L. 2007. A consumer perspective on value creation, Academy of Management Review 32(1): 219-235. http://dx.doi.org/10.5465/AMR.2007.23464055

Ritala, P.; Tidström, A. 2014. Untangling the value-creation and value-appropriation elements of coopetition strategy: a longitudinal analysis on the firm and relational levels, Scandinavian Journal of Management (in press).

Sánchez, R.; Iniesta, M. A. 2006. Consumer perception of value: literature review and a new conceptual framework, Journal of Consumer Satisfaction, Dissatisfaction and Complaining Behavior 19: 40-48.

Sirmon, D. G.; Hitt, M. A.; Ireland, R. D. 2007. Managing firm resources in dynamic environments to create value: looking inside the black box, Academy of Management Review 32(1): 273-292. http://dx.doi.org/10.5465/AMR.2007.23466005 
Smith, J. B.; Colgate, M. 2007. Customer value creation: a practical framework, Journal of Marketing Theory \& Practice 15(1): 7-23. http://dx.doi.org/10.2753/MTP1069-6679150101

Teece, D. J.; Pisano, G.; Shuen, A. 1997. Dynamic capabilities and strategic management, Strategic Management Journal 18(7): 509-533. http://dx.doi.org/10.1002/(SICI)10970266(199708)18:7<509::AID-SMJ882>3.0.CO;2-Z

Tuominen, M. 2004. Channel collaboration and firm value proposition, International Journal of Retail \& Distribution Management 32(4): 178-189. http://dx.doi.org/10.1108/09590550410528953

Ulaga, W. 2001. Customer value in business markets: an agenda for inquiry, Industrial Marketing Management 30(4): 315-319. http://dx.doi.org/10.1016/S0019-8501(01)00151-1

Wang, Y.; Lo, H. P.; Chi, R.; Yang, Y. 2004. An integrated framework for customer value and customer-relationship-management performance: a customer-based perspective from China, Managing Service Quality 14(2/3): 169-182. http://dx.doi.org/10.1108/09604520410528590

Woodall, T. 2003. Conceptualising 'value for the customer': an attributional, structural and dispositional analysis, Academy of Marketing Science Review 2003(12): 1-42.

Woodruff, R. B.; Gardial, S. F. 1996. Know your customer: new approaches to understanding customer value and satisfaction. Cambridge, MA: Blackwell Business.

\section{APPENDIX A}

\section{Questionnaire items and statistical coefficients}

\begin{tabular}{|c|c|}
\hline Construct/dimensions/items & $\begin{array}{c}\text { Standardized } \\
\text { coefficient } \\
\text { (factor loadings } \\
\text { weights) }\end{array}$ \\
\hline \multicolumn{2}{|l|}{ Customer Value Creation $(1=$ much lower and $7=$ much higher $)$. } \\
\hline CV_1: Levels of customer loyalty compared to competitors & 0.62 \\
\hline $\mathrm{CV}_{-}^{-}$2: Levels of customer satisfaction compared to last year & 0.79 \\
\hline $\mathrm{CV}_{-}^{-}$3: Levels of customer loyalty compared to last year & 0.94 \\
\hline \multicolumn{2}{|l|}{ PERCEIVED VALUE } \\
\hline Service Quality $(1=$ strongly disagree and $7=$ strongly agree $)$. & $0.31 * * *(\mathrm{a})$ \\
\hline SQ_1: In general, this bank's service is reliable and consistent & 0.84 \\
\hline SQ_2: My experience with this bank is always excellent & 0.90 \\
\hline SQ_3: I would say that this bank provides superior service & 0.93 \\
\hline SQ_4: Overall, I think this bank provides good service & 0.95 \\
\hline Service Equity ( $1=$ strongly disagree and $7=$ strongly agree $)$. & $0.12 * *(a)$ \\
\hline $\begin{array}{l}\text { SE_1: It makes sense to engage this bank's services compared to others, } \\
\text { even if they are the same }\end{array}$ & 0.76 \\
\hline $\begin{array}{l}\text { SE 2: Even if another bank offers the same service, I would still prefer } \\
\text { this bank }\end{array}$ & 0.91 \\
\hline $\begin{array}{l}\text { SE 3: If another bank offers services as good as this bank's, I would } \\
\text { still prefer this bank }\end{array}$ & 0.91 \\
\hline $\begin{array}{l}\text { SE_4: If another bank is not different from this bank in any way, } \\
\text { it still seems smarter to purchase this bank's services }\end{array}$ & 0.85 \\
\hline
\end{tabular}


End of Appendix A

\begin{tabular}{lc}
\hline Construct/dimensions/items & $\begin{array}{c}\text { Standardized } \\
\text { coefficient } \\
\text { (factor loadings/ } \\
\text { weights) }\end{array}$ \\
\hline Confidence Benefits (1 = strongly disagree and 7 = strongly agree). & $0.40^{* * *(a)}$ \\
\hline CB_1: I have more confidence the service will be performed correctly & 0.90 \\
CB_2: I have less anxiety when I buy/use the services of this bank & 0.86 \\
CB_3: I believe there is less risk that something will go wrong & 0.81 \\
CB_4: I feel I can trust this bank & 0.87 \\
\hline Perceived Sacrifice (1 = strongly disagree and 7 = strongly agree). & $-0.04^{\text {ns(a) }}$ \\
\hline PS_1: The price charged for this bank's services is high & $0.47^{\mathrm{a}}$ \\
PS_2: The time required to receive this bank's services is high & $0.10^{\mathrm{a}}$ \\
PS_3: The effort I expend to receive this bank's services is high & $0.43^{\mathrm{a}}$ \\
\hline
\end{tabular}

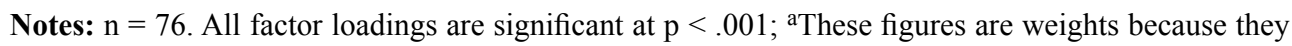
are associated with formative dimensions.

Silvia MARTELO-LANDROGUEZ is PhD in Management. Currently, she is an assistant professor in the Management and Marketing Department at the University of Seville. Her research topics are dynamic capabilities, market orientation, knowledge management, customer relationship management and customer value.

Carmen BARROSO-CASTRO is PhD in Management. She is a Professor of Business Administration in the Management and Marketing Department at the University of Seville. At present, her main research topics are related to resource-based theory and customer value.

Gabriel CEPEDA is PhD in Management. Currently, he is an associate professor in the Management and Marketing Department at the University of Seville. His research topics include organizational learning, knowledge management and qualitative and quantitative research methods. 